Uşak Üniversitesi Sosyal Bilimler Dergisi

$2014,7(1), 1-23$

\title{
Kamu İç Denetiminin Organizasyon ve Mevzuat Perspektifinde Değerlendirilmesi Üzerine Bir Çalışma
}

Serkan AKÇAY*

\begin{abstract}
Özet
İç denetim; kurumun her türlü etkinliğini denetlemek, geliştirmek, iyileştirmek ve kuruma değer katmak amacıyla, bağımsız ve tarafsız bir şekilde güvence ve danışmanlık hizmeti vermek için düzenlenmiş olan bir denetim sistemidir. İç kontrolün etkinliğini ölçecek olan iç denetim birimidir. İç denetim, Türkiye için, kamu yönetiminde şeffaflaşma ve Avrupa Birliği'ne giriş için de önemli bir rol oynamaktadır. 5018 Sayılı Kamu Mali Yönetimi ve Kontrol Kanununun kabulü ile iç denetimin Türkiye'de kamu sektöründe yerleşmesi için çok önemli bir adım atılmıştır. Araştırmanın amacı, kamu kurumlarında iç denetimin yapılanmasına organizasyon ve mevzuat perspektifinde bakmaktır. Bunun için, belediyelerde görevli 110 adet iç denetçiye anket uygulanmıştır. Ankette, iç denetimin yapısı üzerinde olumlu ya da olumsuz etkisi olan faktörler incelenmiştir. Önemli bulgular elde edilmiştir. Ayrıca, iç denetimin yapısında bazı değişikliklerin yapılmasının iç denetimin etkinliğini artırabileceğine dair tespitlerde bulunulmuştur.
\end{abstract}

Anahtar Kelimeler: İç Denetim, Kamu, Organizasyon, Mevzuat

\section{A Study on Evaluation of the Public Internal Audit in Terms of The Organization and Legislation}

\begin{abstract}
Internal audit is a control system that is organized to give an assurance and consultancy service in an independent and impartial manner for purpose of auditing, developing and improving every activity of an institution and for adding value to it. What measures the effectiveness of internal audit is the internal auditing unit. Internal audit plays an important role in making the auditing, developing and improving every activity of an institution and for adding value to it. What measures the effectiveness of internal audit is the internal auditing unit. Internal audit plays an important role in
\end{abstract}

*Yrd. Doç. Dr., Artvin Çoruh Üniversitesi, İktisadi ve İdari Bilimler Fakültesi, İşletme Bölümü 
making the public management transparent and entering into the European Union. With acceptance of 5018 No Public Financial Management and Control Law, very important steps have been taken for establishment of internal audit in the public sector of Turkey. The purpose of this study is to look at the structure of internal audit in public institutions the organization and legislation perspective. For this purpose, a questionnaire was applied to 110 internal auditors who worked for municipalities. In the questionnaire, has been examined the factors of a positive or negative effect on the structure of the internal audit. Important findings were obtained. Besides, it was determined that some alterations in structure of internal audit may increase the effectiveness of internal audit.

Key Words: Internal Audit, Public, Organization, Legislation

\section{Giriş}

Türkiye'de, kamu kurumlarında geleneksel denetimden sonra yakın zamanda uygulanma imkânı bulan iç denetimin amacı, kurum iç kontrolünün etkin çalışıp çalışmadığının denetimidir. Geleneksel anlamıyla denetim, karar verme sürecinin son aşamasında tüm diğer işletme fonksiyonlarına tepeden bakarak bir durum değerlendirmesi yapma işlemidir. Kontrol ise genel anlamıyla, planlanan bir hedefe ulaşılıp ulaşılmadığının araştırılmasıdır (Hermanson, 1994: 29). İç denetimin hedefi, kurum iç kontrolünü sürekli iyileştirmek ve bunun sonucunda da kurum süreçlerinin etkinliğini ve verimliliğini sağlayarak, faaliyet sonuçlarını sürekli iyileştirmeye tabi tutup katma değer meydana getirmektir.

Bu amaçlar ışığında kamuda yapılanan iç denetimde süreç maalesef ağır işlemiştir. 2003 yılında 5018 Sayılı Kamu Mali Yönetimi ve Kontrol Kanununun kabulünden sonra, iç denetim ile ilgili hususlar 01.01.2006 yılında yürürlüğe girmiş olsa da, 2006-2008 yılları arasında iç denetimle ilgili bir geçiş süreci yaşanmıştır. Bu iki yıllık süreçte, iç denetçi atamaları yapılarak, atanan bu iç denetçilerin eğitimleri tamamlanmaya çalışılmıştır. Atama ve eğitim süreçlerinden sonra, iç denetim birimlerinin oluşturularak kamu kurumlarında iç denetimin fiili olarak başlaması ise bazı kurumlarda 2008 yılını, kurumların büyük bir çoğunluğunda ise 2009 yılını bulmuştur. Hâlihazırda 2013 yılı olmasına rağmen iç denetim birimi kurulmamış veya iç denetçi ataması yapmamış kamu kurumlarının da bulunması sürecin ağır işlemesine verilebilecek en güzel örnektir.

Çalışmada ilk önce iç denetimin organizasyonu ve mevzuatı konusunda teorik bilgiler verilmiş olup, daha sonra da araştırmanın amacı ve önemi belirtilerek konu ile ilgili literatür taraması yapılmıştır. Son olarak 
da, araştırmanın yöntem ve hipotezleri belirlenerek araştırmanın bulguları ortaya konulmuş ve araştırmanın sonucu özet olarak belirtilmiştir.

\section{İç Denetimin Tanımı}

İç denetim, kamu idaresinin çalışmalarına değer katmak ve geliştirmek için kaynakların ekonomiklik, etkililik ve verimlilik esaslarına göre yönetilip yönetilmediğini değerlendirmek ve rehberlik yapmak amacıyla yapılan bağımsız, nesnel güvence sağlama ve danışmanlık faaliyetidir. Temel amaç, üst yönetimin sorumluluklarını yerine getirmesine yardımcı olmaktır (Haftacı, 2011: 65). İşletmeye amaçlarına ulaşmasında yardımcı olmak iç denetimin en temel görevlerinden biridir (Chapman ve Anderson, 2003: 3). İç denetim, bir şirkette kurmay görevi üstlenmiş firma çalışanlarınca sonuçları sadece firma içi raporlanmak amacıyla yapılan bir denetimdir. $\mathrm{Bu}$ denetimde mali nitelikteki faaliyetler ile mali nitelikte olmayan faaliyetler gözden geçirilir, değerlendirilmesi yapılır ve sonuçları işletme yönetimine rapor edilir (Ergin, 2007: 8).

Başka bir ifadeyle iç denetim, kurum faaliyetlerinin, para ve mal hareketlerinin, kurum çalışanlarının eylemlerinin, aynı kuruma bağlı denetim birimince denetlenmesidir. İç denetim, faaliyetlerin etkinliğini ve verimliliğini esas alır. İşletmede görevli kişilerin tutum ve davranışlarını denetler. Tavsiyelerde bulunur. İşletmedeki iç kontrolün etkinliğini arttırmayı ve bu sistemi test etmeyi amaçlar (Güçlü, 2008: 5). Kısaca ifade etmek gerekirse etkin bir iç kontrol sistemi için, uygun bir iç denetim ortamı ve etkin bir iç denetim faaliyeti gereklidir (Dabbağoğlu, 2007: 164).

İç denetimin kapsamında mali, uygunluk, sistem, performans ve bilgi teknolojileri denetimleri yer alır (Jack ve diğ., 1994).

Mali denetim; bir kuruma ait mali tabloların önceden belirlenmiş kriterlere uygun olarak düzenlenip düzenlenmediği konusunda bir görüş belirlemek amacıyla bu mali tabloların incelenmesini kapsar. Bu kriterler genel kabul görmüş muhasebe ilkeleri veya vergi mevzuatı hükümleridir (Kenger, 2001).

Uygunluk denetimi ise; bir kurumun mali işlemlerinin ve diğer faaliyetlerinin belirlenmiş yöntemlere, kurallara ve mevzuata uygun olup olmadığını belirlemek amacıyla incelenmesidir (Alptürk, 2008: 22).

Sistem denetimi; denetlenen sürecin ya da birimin amaçlarına ulaşmasını sağlamada iç kontrol sistemlerinin yeterlik ve etkinliğinin değerlendirilmesidir (Aksoy, 2008: 86).

Performans denetimi; denetlenen kurum kaynaklarının verimlilik, etkinlik ve tutumluluk esasları çerçevesinde yönetilip yönetilmediğini anlamak için faaliyetlerin bağımsız bir şekilde değerlendirilmesi olarak 
tanımlanabilir (Sayıştay, 2002: 1).

Bilgi teknolojileri denetimi ise; denetlenen birimin elektronik bilgi sistemlerinin güvenilirliğinin ve sürekliliğinin değerlendirilmesi sürecidir. $\mathrm{Bu}$ denetim türü ayrıca denetlenen bilgi sisteminde depolanan veri ve bilgilerin yeterliliğini ve doğruluğunu değerlendirmek için kullanılır. Bilgi sisteminin güvenliği, depolanmış bilgilerin yanlış kullanılmasının, zarara uğratılmasının ya da yok edilmesinin önlenme derecesi olarak belirtilebilir (Karaaslan, 2006: 337).

\section{Kamu İç Denetiminin Organizasyonu}

Kamuda iç denetimin organizasyonu için en önemli adım, 5018 Sayılı Kamu Mali Yönetimi ve Kontrol Kanunu 10.12.2003 tarihinde kabul edilerek 24.12.2003 tarih ve 25326 sayılı Resmi Gazete'de yayınlanmasıyla atılmıştır. 5018 sayılı kanunun bir çok maddesinde değişiklik öngören 5436 Sayılı Kanun ise 22.12.2005 tarihinde kabul edilerek 24.12.2005 tarih ve 26033 sayılı Resmi Gazetede yayınlanmış ve iki maddesi dışında 01.01.2006 tarihinde yürürlüğe girmiştir. İç denetim ile ilgili maddeler de bu tarih itibarıla yürürlüğe girmiştir. 5018 sayılı kanunla genel yönetim kapsamındaki idarelerin bütçeleri; merkezi yönetim bütçesi, sosyal güvenlik kurumları bütçesi ve mahalli idareler bütçesi olarak düzenlenmiştir. Ayrıca, 5018 sayılı kanunla sorumlular; siyasi açıdan bakanlar ve idari açıdan üst yöneticiler yanında harcama sürecinde idari ve mali açıdan ise, harcama yetkilisi, mali kontrol yetkilisi, gerçekleştirme görevlisi ve muhasebe yetkilisi şeklinde sayılmıştır (Arslan, 2004).

5018 sayılı kanun kamu kaynaklarını etkili, ekonomik ve verimli bir şekilde elde edilmesi ve kullanılmasını, hesap verilebilirliği ve mali saydamlığı sağlamak üzere, kamu mali yönetiminin yapısını ve işleyişini, kamu bütçelerinin hazırlanmasını, uygulanmasını, tüm mali işlemlerin muhasebeleştirilmesini, raporlanmasını ve mali kontrolünü düzenlemek üzere hazırlanmıştır. Bu kanunla, 1050 sayılı kanundan farklı olarak mali yönetim yapısı da düzenlenmektedir. 1050 sayılı kanunda esas olarak mali usul düzenlenmekte, mali yetki ve sorumluluklar idari yapıya bağlı görevler olarak tanımlanmakta idi (Saraç, 2005: 27). 


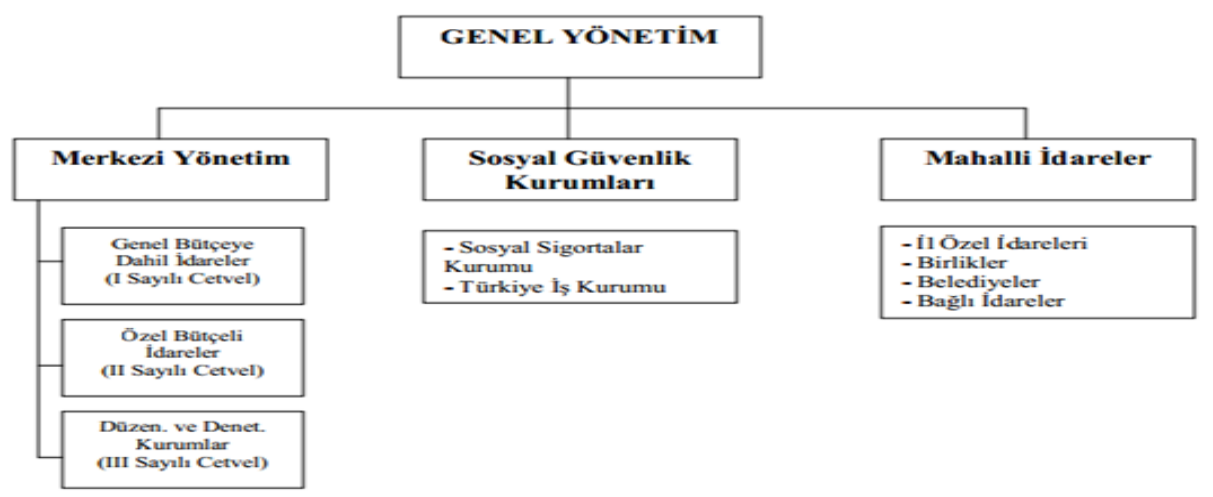

(Kaynak: Arcagök ve Erüz, 2006: 31)

Şekil 1: 5018 Sayılı Kanun Kapsamı

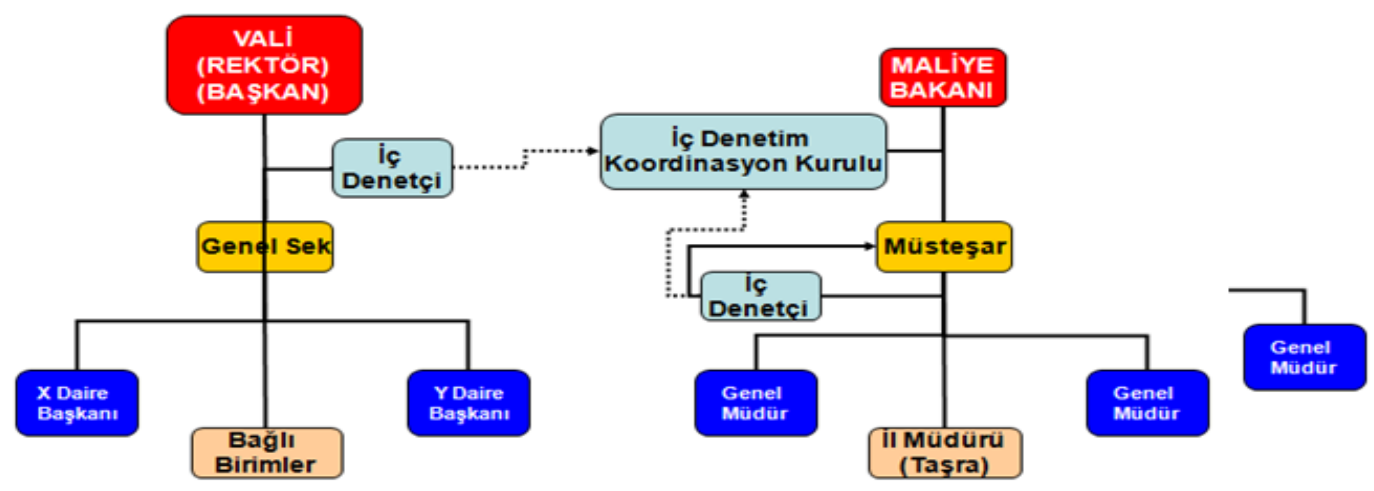

(Kaynak: Başpınar, 2009)

Şekil 2: İç Denetim'in 5018 Sayılı Kanun'daki Yeri

\section{Kamu İç Denetiminde Adı Geçen Sorumlular}

İç denetimde adı geçen sorumlular ve görevleri özetle şunlardır (Başpınar, 2009):

Üst Yönetici: Sistemi kurmak, geliştirmek ve gözetlemek görevlerinden sorumludur.

Mali Hizmetler Birimi: Sistemin kurulması, geliştirilmesi, gözetilmesi çalışmalarını yürütmek, üst yöneticiye önerilerde bulunmak ve ön mali kontrol görevlerini yerine getirmekle yükümlüdür. 


\section{S. AKÇAY $\mid 6$}

Harcama Yetkilisi: Harcama talimatı vermek, iç kontrol ve ön mali kontrolü uygulamak ve süreç kontrolünü izleme görevlerinden sorumludur.

Gerçekleştirme Görevlisi: Harcama talimatı üzerine gideri gerçekleştirme ve süreç kontrolü görevlerini yerine getirir.

Muhasebe Yetkilisi: Ödemelerde kontrol yapmak, muhasebe kayıtlarını usulüne ve standartlara uygun bir şekilde tutmak, muhasebe işlemleri ve raporların saydamlığını sağlamak görevlerini yerine getirir.

İç Denetçi: Özetle, idarelerin risk yönetimi, yönetim ve kontrol süreçlerinin etkinliğini değerlendirmek ve geliştirmek görevlerinden başlıcalarıdır.

İç Denetim Koordinasyon Kurulu : İç denetime ilişkin denetim ve raporlama standartlarını belirlemek, denetim rehberlerini hazırlamak ve geliştirmek, uluslararası uygulamalar ve denetim standartlarıyla uyumlu risk değerlendirme yöntemlerini geliştirmek, iç denetçilerin eğitim programlarını düzenlemek, idarelerin iç denetim raporlarını değerlendirerek sonuçlarını konsolide etmek suretiyle yıllık rapor halinde Maliye Bakanına sunmak ve kamuoyuna açıklamak, İç denetçilerin atanmasına ilişkin diğer usulleri belirlemek ve iç denetçilerin uyacakları etik kuralları belirlemek gibi görevleri yerine getirir.

\section{Kamu İç Denetimi Mevzuatı}

İç denetimin mevzuatı üç aşamada gerçekleştirilmiş olmakla beraber, mevzuat üzerinde değişiklikler ve ilaveler halihazırda devam etmektedir. Mevzuat ana başlıklarıyla şu kanun, yönetmelik, karar ve rehberlerden oluşmaktadır.

a) Birincil Düzey Mevzuat

- 5018 Sayılı Kanunun İlgili Maddeleri

- 5018 Değişikliği

- 5034 Sayılı Kanunun İlgili Maddeleri (IDKK, 2012).

b) İkincil Düzey Mevzuat

- İç Denetçilerin Çalışma Usul ve Esasları Hakkında Yönetmelik

- İç Denetçi Adayları Belirleme, Eğitim ve Sertifika Yönetmeliği

- İç Denetim Koordinasyon Kurulunun Çalışma Usul ve Esasları Hakkında Yönetmelik

- Ek Ödemeye İlişkin Usul ve Esasların Belirlenmesine İlişkin Bakanlar Kurulu Kararı

- Kadro Tahsisi İle İlgili Bakanlar Kurulu Kararı

- Mahalli İdareler Kadro Tahsisi ile İlgili Bakanlar Kurulu Kararı (IDKK,2012). 
c) Üçüncül Düzey Mevzuat

- Üst Yönetici Rehberi

- Kamu İç Denetim Standartları

- Kamu İç Denetçileri Meslek Ahlak Kuralları

- Kamu İç Denetim Birim Yönergesi

- Kamu İç Denetim Raporlama Standartları

- Birden Fazla Kamu İdaresi İç Denetçilerinin Ortak Çalışma Esas ve Usulleri

- Kamu İç Denetçi Sertifikasının Derecelendirilmesine İlişkin Esas ve Usuller

- Kamu İç Denetim Planı ve Programı Hazırlama Rehberi

- Kamu İç Denetiminde Risk Değerlendirme Rehberi

- Kamu İç Denetimi Strateji Belgesi (2008-2010)

- Kamu İç Denetçi Mesleki Kıdemin Belirlenmesine İlişkin Esas ve Usuller

- Kamu İç Denetim Rehberi

- Kamu İç Denetim Terimleri Sözlüğü (Public Internal Audit Glossary)

- Kamu İç Denetçi Sertifikasının İptaline İlişkin Esas ve Usuller

- İç Denetçi Atamalarında Uyulacak Esas ve Usuller Hakkında Tebliğ

- İç Denetçi Adaylarının Belirlenmesinde Uy. Esas ve Usuller Hakkında Tebliğde Değerlendirme Yapılmasına Dair Tebliğ

- 2011-2013 Dönemi Kamu İç Denetimi Strateji Belgesi

\section{Araştırmanın Amacı ve Önemi}

Araştırmanın amacı, ülkemizde yakın zamanda kamu kurumlarında uygulanmaya başlanan iç denetimin yapisal bağlamda etkin çalışıp çalışmadığının tespitidir. İç denetimin organizasyonu ve mevzuatının kamu kurumlarının faaliyet sonuçlarına etkisinin ne ölçüde olduğunun ortaya koyulmasidır.

Araştırmanın önemi ise, kamu mali yönetimi ve denetimi; bütçeleme, muhasebe, nakit yönetimi, borç yönetimi, iç kontrol mekanizmaları ve denetim öğelerinden oluşur. Gerek literatürde ve gerekse uygulamada, bu faaliyetlerden bütçelemeye aşırı önem verildiği, diğerlerinin ise yeterince önemsenmediği görülmektedir. Hâlbuki mali yönetimin öğelerinin tümü gereği gibi işletilmedikçe, hesap verme yükümlülüğü de tam olarak yerine getirilemez. İşte bu noktada iç denetim devreye girmektedir. İç denetim kamuda şeffaflaşma ve yöneticilerin hesap verebilme özelliğini geliştirerek, kamuda yolsuzlukların önüne geçerek önemli bir fonksiyonu yerine getirmiş olmaktadır.. 


\section{Araştırmanın Problemi}

Türkiye'de iç denetime 1980'li yıllarda ilk özel sektörde başlanmış ve uygulamanın yaygınlaşması ile 1995 yılında "Türkiye İç Denetim Enstitüsü" (TIDE) kurulmuştur. 2000'li yıllarda Bankacılık gözetimine ilişkin Basel Komitesi, bankalar için bazı iç denetim faaliyetlerini zorunlu kılmıştır. 2003 yılında yürürlüğe giren 5018 Sayılı Kamu Mali Yönetimi Kontrol Kanunu ile kamu kurumlarında iç denetim zorunlu hale getirilmiştir. Kanun'un 63.maddesinde iç denetimin uluslar arası kabul görmüş standartlara uygun olarak sertifikalı iç denetçiler tarafından yapılacağı, kamu idarelerinde doğrudan üst yöneticiye bağlı iç denetim birimi başkanlıklarının faaliyete geçirileceği ifade edilmiştir. Araştırma problemi, iç denetimin yapısının organizasyon ve mevzuat açısından kamuda etkin çalışıp çalışmadığı sorusudur. Bu çalışmayla, iç denetimde sorunların tespiti, çözümü ve iç denetimin mevzuat ve organizasyon açısından daha da iyileştirilebilmesi için neler yapılması gerektiğine dair sorulara cevap alınmaya çalışılmıştır.

\section{Literatür Taraması}

Kamuda iç denetimin ve belediyelerin etkinliği ve etkinlik ölçümüyle ilgili literatür taraması sonucu tespit edilen yayınlar şunlardır:

2006 yılında, "Yerel Yönetimlerde Performans Ölçümü ve Dışsal Faktörlerin Yerel Yönetimlerin Performansına Etkisi Üzerine Bir Araştırma" adlı doktora tezinde (Bilge, 2006), Türkiye'deki BEPER Projesi kapsamındaki yerel yönetimlerin performanslarını ölçmek için kullanılan "başarı göstergeleri" üzerinde dişsal faktörlerin etkilerini ölçmeye yönelik istatistikî bir model kurulmuş ve elde edilen sonuçlar yorumlanmıştır.

2007 yılında, "Büyükşehir Belediye Hizmetlerinin Göreceli Etkinlik Analizi" adlı yayında (Güneş ve Akdoğan, 2007), toplu taşıma, sukanalizasyon ve kolluk - esenlik gibi üç temel yerel hizmetin sunumunda ülkemizdeki Büyük Şehir Belediyelerinin göreli etkinliklerini Veri Zarflama Analizi yöntemiyle belirlemektir. Belediyelerin hizmet bazında etkinlikleri hesaplanmıştır.

2008 yılında "Belediye Hizmetlerine İlişkin Algı ve Memnuniyetin İkili Lojistik Regresyon Analizi İle Ölçümü: Eskişehir İli Örneği" adlı yüksek lisans tezinde (Cankuş, 2008), Eskişehir ilinde belediye hizmetlerinden faydalananların belediye yönetim algılamaları ve belediye hizmetlerinden memnuniyetlerinin ikili lojistik regresyon analizi ile ölçülmesi amaçlanmıştır. Eskişehir ilindeki iki alt kademe belediye ele alınarak, her iki belediyeye bağlı tabakalı örnekleme yöntemiyle seçilen mahallelerdeki 18 yaş üstü toplam 2110 bireye anket uygulanmıştır. Bireylerin memnuniyetleri 
Sosyal Bilimler Dergisi 9

ile ilgili binomial düzeyde gizil değişken kullanılarak uygulanan ilk modelde, her iki belediyeye bağlı mahallelerde uygulanan anket sonuçları değerlendirilerek, bireylerin belediye hizmetlerinden memnuniyetleri üzerinde anlamlı ve etkili olan değişkenler; cinsiyet, eğitim durumu, meslek, aylık gelir ve mahallede oturma süresi açısından değerlendirilmiştir.

Yine 2008 yılında, “Kamu Harcamalarında Etkinliğin Sağlanması Bakımından İç Denetimin Rolü", adlı yüksek lisans tezinde (Sarıkaya, 2008), Avrupa Birliği'ne giriş sürecinde, kamu harcama denetiminin daha etkin hale getirilmesine yönelik ne gibi düzenlemelere ihtiyaç duyulduğu hususları değerlendirilmeye çalışılmıştır. 5018 Sayılı Kamu Mali Yönetimi ve Kontrol Kanunu çerçevesinde iç denetim incelenmiştir.

2009 yılında, "Yerel Yönetimlerde Performans Ölçümü ve Benzer Tip Belediyelerde Mali performans Uygulamaları" adlı yayında (Ağcakaya, 2009), Isparta, Afyonkarahisar ve Kütahya Belediyesinin 2002-2003 ve 2004 yıllarına ait verileri kullanılarak belediyelerin mali performansı ölçülmüştür. 2011 yılında, “Maliyet Etkinlik Analizi: Türkiye'deki Büyükşehir Belediyelerinde Uygulama" adlı yayında (Kaygısız ve Girginer, 2011), Türkiye'deki Büyükşehir belediyelerinin kendilerine tahsis edilen bütçeyle hizmetlerini ne derece doğru gerçekleştirdiklerinin belirlenmesi amaçlanmıştır. Elde edilen bulgular, performans ölçümünde maliyet etkinlik oranlarının etkinlik oranlarına göre daha gerçekçi sonuçlar ortaya koyduğunu göstermiştir.

\section{Araştırmanın Yöntemi}

Araştırmanın modeli, evren-örneklem, veri toplama araçları ve analizler bilimsel yöntemlerle yapılmış ve değerlendirilmiştir.

\section{Araştırmanın Modeli}

$\mathrm{Bu}$ araştırma "tarama modeli" olarak tasarlanmıştır. "Tarama modelleri, geçmişte ya da halen var olan bir durumu var olduğu şekilde betimlemeyi amaçlayan araştırma yaklaşımlarıdır. Araştırmaya konu olan olay, birey ya da nesne, kendi koşulları içinde ve olduğu gibi tanımlanmaya çalışılır. Onları herhangi bir şekilde değiştirme, etkileme çabası gösterilmez" (Karasar, 2009: 77).

\section{Araştırmanın Hipotezleri}

Konuyla ilgili yapılan araştırmada bir bağımlı ve iki adet bağımsız değişken kullanılmıştır. Araştırma'nın hipotezleri;

$\mathrm{H}_{1}$ : İç denetimin etkin bir şekilde yapılması ile kurumun faaliyet sonuçları arasında anlamlı bir ilişki vardır. 
$\mathrm{H}_{1 a}$ İç denetimin doğru organizasyonu ile iç denetimin etkin bir şekilde yapılması arasında anlamlı bir ilişki vardır.

$\mathrm{H}_{1 b}$ : İç denetimin mevzuatının doğru uygulanması ile iç denetimin etkin bir şekilde yapılması arasında anlamlı bir ilişki vardır.

\section{Araştırmada Evren-Örneklem}

Araştırmada veri toplama aracı olarak kullanılan "İç Denetim" başlıklı anketin evreni, Türkiye genelinde iç denetim uygulaması yapılan belediyelerde görev yapan 272 adet iç denetçidir. Örneklem ise, aynı belediyelerde görev yapan 110 adet iç denetçidir.

\section{Veri Toplama Araçları}

Araştırmada, belirlenmiş olan hipotezlerin sınanması için, çoktan seçmeli otuz sorudan oluşan ve $\% 78,4$ güvenilirlik ölçeğine sahip anket kullanılmıştır. Anket soruları, iç denetimin yapısı ve mevzuatı ilgili araştırmalar tamamlandıktan sonra soruların iç denetimle ilgili bütün alanları kapsamasına önem verilmiştir. İç denetimle ilgili ankette belirlenmiş olan üç alanı kapsayacak şekilde bir soru havuzu oluşturulmuş ve daha sonra da bu soru havuzundan seçimler yapılarak ilgili bölümün alt soruları şeklinde düzenlenme yapılmıştır.

\section{Güvenirlik}

Otuz sorudan oluşan ölçeğin genel güvenirliği $\alpha=0,784$ olarak bulunmuştur.

Tablo 1: Ölçeğin Alt Boyutlarının İç Tutarlılıkları

\section{Alt Boyutlar}

İç denetimin Organizasyonu

İç denetim mevzuatı

İç denetim sonrası kurum faaliyet sonuçları
Cronbach's

Alpha

0,790

0,733

0,785 
İç denetimin organizasyonu alt boyutunun iç tutarlılığg $\alpha=0,790$, iç denetim mevzuatı alt boyutunun iç tutarlılığ $\alpha=0,733$ ve iç denetim sonrası kurum faaliyet sonuçları alt boyutunun iç tutarlılığ $\alpha=0,785$ olarak bulunmuştur.

Cronbach's Alpha Katsayısının değerlendirilmesinde kullanılan değerlendirme kriteri (Özdamar, 2004);

$0,00 \leq \alpha<0,40$ ise ölçek güvenilir değildir.

$0,40 \leq \alpha<0,60$ ise ölçek düşük güvenilirliktedir.

$0,60 \leq \alpha<0,80$ ise ölçek oldukça güvenilirdir.

$0,80 \leq \alpha<1,00$ ise ölçek yüksek derecede güvenilir bir ölçektir.

Araştırmada kullanılan likert ölçek için kişilerin verilen önermelerle ilgili görüşlerini, çok olumludan çok olumsuza kadar sıralanan seçeneklerden belirtmeleri istenmiştir. Buna göre; (5) kesinlikle katılıyorum, (4) katılıyorum, (3) kararsızım, (2) katılmıyorum, (1) kesinlikle katılmıyorum şeklinde bir ölçek kullanılmıştır. Ölçek sonuçları $5.00-1.00=4.00$ puanlık bir genişliğe dağılmışlardır. $\mathrm{Bu}$ genişlik beşe bölünerek ölçeğin kesim noktalarını belirleyen düzeyler belirlenmiştir. Ölçek ifadelerinin değerlendirilmesinde aşağıdaki kriterler esas alınmıştır.

Tablo 2: Ölçek Değerlendirme Kriterleri

\begin{tabular}{lccc} 
Seçenekler & Puanlar & Puan Aralığı & Ölçek Değerlendirme \\
\hline $\begin{array}{l}\text { Kesinlikle } \\
\text { Katılmıyorum }\end{array}$ & 1 & $1,00-1,79$ & Çok düşük \\
Katıllyorum & 2 & $1,80-2,59$ & Düşük \\
Kararsızım & 3 & $2,60-3,39$ & Orta \\
Katıllyorum & 4 & $3,40-4,19$ & Yüksek \\
Kesinlikle Katıllyorum & 5 & $4,20-5,00$ & Çok yüksek \\
\hline
\end{tabular}

\section{Verilerin Analizi}

Araştırmada elde edilen veriler SPSS paket programı kullanılarak analiz edilmiştir. Verileri değerlendirilirken tanımlayıcı istatistiksel 
metotları (Sayı, Yüzde, Ortalama, Standart sapma) kullanılmıştır. Araştırmanın değişkenleri için Kormogrov Smirnov-Normal Dağılım testi uygulanmıştır. Değişkenlerin normal dağıldıkları tespit edilmiştir. Verilerin analizleri yapılırken parametrik olmayan yöntemler kullanılmıştır. Niceliksel verilerin karşılaştırılmasında iki grup arasındaki farkı bağımsız ttesti, ikiden fazla grup durumunda parametrelerin gruplararası karşılaştırmalarında One-Way ANOVA testi kullanılmıştır. Araştırmanın bağımlı ve bağımsız değişkenleri arasındaki ilişki Pearson korelasyon analizi ve regresyon analizi ile test edilmiştir. Ölçekler arasındaki korelasyon ilişkileri aşağıdaki kriterlere göre değerlendirilmiştir (Kalaycı, 2006: 116).

Tablo 3: Ölçek Korelasyon İlişkisi Kriterleri

$\begin{array}{cll}\frac{1}{0,00-0,25} & & \text { İlişki } \\ 0,26-0,49 & & \text { Zayıl Zayıf } \\ 0,50-0,69 & & \text { Orta } \\ 0,70-0,89 & & \text { Yüksek } \\ 0,90-1,00 & & \text { Çok Yüksek }\end{array}$

Elde edilen bulgular \%95 güven aralığında $\% 5$ anlamlılık düzeyinde değerlendirilmiştir.

\section{Bulgular}

Araştırmada anket ile önemli bulgular elde edilip yorumlanmıştır. Anket sorularının hazırlanmasında, gerek daha önce yapılan araştırmalar literatür taraması yapılarak incelenmiş, gerekse de iç denetimin yapısı, mevzuatı ve süreci incelenerek bir soru havuzu oluşturulmuş ve oluşturulan bu soru havuzundan iç denetimi tamamıla kapsayacak gruplandırmalar yapılmış ve sorular üç ana grupta toplanarak iç denetçilere uygulanmıştır.

Tablo 4: Örneklem Grubunun Yaşlarına Göre Dağılımı

$$
\text { Frekans Yüzde (\%) }
$$




$\begin{array}{lll}\text { 32-37 yaş } & 22 & 20,0 \\ 38-43 \text { yaş } & 23 & 20,9 \\ 44-49 \text { yaş } & 32 & 29,1 \\ 50-55 \text { yaş } & 22 & 20,0 \\ 56 \text { yaş ve üstü } & 11 & 10,0\end{array}$

Tablo 5: Örneklem Grubunun Cinsiyetlerine Göre Dağılımı

$\begin{array}{lll} & \text { Frekans } & \text { Yüzde (\%) } \\ \text { Erkek } & 100 & 90,9 \\ \text { Kadın } & 10 & 9,1\end{array}$

Tablo 6: Örneklem Grubunun Mesleki Kıdemlerine Göre Dağılımı Frekans Yüzde (\%)

$\begin{array}{lll}10 \text { yıl ve altı } & 70 & 63,6 \\ 11-20 \text { yıl } & 19 & 17,3 \\ 21 \text { yıl ve üstü } & 21 & 19,1\end{array}$

Tablo.7: Normallik Testi

One-Sample Kolmogorov-Smirnov Test

$\begin{array}{lllll} & & \begin{array}{l}\text { iç denetimin } \\ \text { yapısı ve } \\ \text { işleyişi }\end{array} & \begin{array}{l}\text { iç denetim } \\ \text { mevzuatı }\end{array} & \begin{array}{l}\text { iç denetim } \\ \text { sonrası } \\ \text { faaliyet } \\ \text { sonuçları }\end{array} \\ \mathrm{N} & 110 & 110 & 110 \\ \begin{array}{l}\text { Normal } \\ \text { Parameters }{ }^{\mathrm{a}, \mathrm{b}}\end{array} & \text { Mean } & 3,1618 & 3,2109 & 3,2691 \\ & \begin{array}{l}\text { Std. } \\ \text { Deviation }\end{array} & , 45534 & , 31106 & , 55335\end{array}$




$\begin{array}{lcccc}\begin{array}{l}\text { Most Extreme } \\ \text { Differences }\end{array} & \text { Absolute } & , 092 & , 081 & , 089 \\ & \text { Positive } & , 053 & , 081 & , 048 \\ & \text { Negative } & -, 092 & -, 067 & -, 089 \\ & & \\ \text { Kolmogorov-Smirnov Z } & , 964 & , 847 & , 348 \\ \text { Asymp. Sig. (2-tailed) } & , 310 & , 470 & ,\end{array}$

Tablo 8: Araştırmaya Katılan Kamu İç Denetçilerinin İç Denetim Etkinlik Düzeylerinin Ortalamaları

N Ort. S.s Min. Max.

İç denetim sonrası kurum faaliyet $110 \quad 3,269 \quad 0,553 \quad 1,600 \quad 4,800$ sonuçları

İç denetimin organizasyonu

$110 \quad 3,162 \quad 0,455 \quad 2,100 \quad 4,100$

İç denetim mevzuatı

$110 \quad 3,211 \quad 0,311 \quad 2,500 \quad 4,000$ 
Sosyal Bilimler Dergisi 15

Tablo 9: Kurumun İç Kontrolünün Yeterliliğini Ölçmedeki Etkinliği İle İlgili "İç Denetimin Organizasyonu" Sorularına Verilen Cevapların Ortalaması

\begin{tabular}{|c|c|c|c|c|c|}
\hline & $\mathbf{N}$ & Ort. & S.s & Min. & Max. \\
\hline $\begin{array}{l}\text { Iç denetim, geleneksel denetime göre daha etkin ve } \\
\text { başarilı sonuçlar alan bir yaprya sahiptir. }\end{array}$ & 110 & 4,082 & 1,006 & 1,000 & 5,000 \\
\hline $\begin{array}{l}\text { Iç denetim, geleneksel denetime göre daha karmaşık bir } \\
\text { yapıya sahiptir. }\end{array}$ & 110 & 3,327 & 1,212 & 1,000 & 5,000 \\
\hline $\begin{array}{l}\text { Iç denetim, denetleme konusunda bağımsız bir yapıya } \\
\text { sahiptir. }\end{array}$ & 110 & 3,064 & 1,214 & 1,000 & 5,000 \\
\hline $\begin{array}{l}\text { Iç denetim, yolsuzlukları başlamadan önleyecek bir } \\
\text { yaprya sahiptir. }\end{array}$ & 110 & 3,700 & 0,982 & 1,000 & 5,000 \\
\hline $\begin{array}{l}\text { Iç denetçilerin kadro olarak çalıştığı kuruma bağlı olarak } \\
\text { devam etmesi, denetimin etkinliği açısından gereklidir. }\end{array}$ & 110 & 2,509 & 1,247 & 1,000 & 5,000 \\
\hline $\begin{array}{l}\text { Iç denetçilerin kadro olarak Sayıştay, I.D.K.K. vb. bir } \\
\text { başka kuruma bağlanması, denetimin etkinliği açısmdan } \\
\text { olumlu sonuçlar doğurabilir. }\end{array}$ & 110 & 3,845 & 1,258 & 1,000 & 5,000 \\
\hline $\begin{array}{l}\text { Iç denetçilerin, disiplin ve sicil amirinin üst yönetici } \\
\text { olması doğru bir uygulamadır. }\end{array}$ & 110 & 2,964 & 1,361 & 1,000 & 5,000 \\
\hline $\begin{array}{l}\text { Iç denetçinin soruşturma açma yetkisinin olmaması doğru } \\
\text { bir uygulamadır. }\end{array}$ & 110 & 3,336 & 1,206 & 1,000 & 5,000 \\
\hline $\begin{array}{l}\text { Iç denetimin etkin bir şekilde yürütülebilmesi için, idare } \\
\text { yapısında yetki devri işlemleri titizlikle yapılmaktadır. }\end{array}$ & 110 & 3,027 & 1,062 & 1,000 & 5,000 \\
\hline $\begin{array}{l}\text { Iç Denetim Koordinasyon Kurulunun iç denetimin } \\
\text { yapısmdaki yeri ve rolü etkin bir iç denetim için } \\
\text { yeterlidir. }\end{array}$ & 110 & 1,764 & 0,985 & 1,000 & 5,000 \\
\hline
\end{tabular}




\section{S. AKÇAY $\mid 16$}

Tablo 10: Kurumun İç Kontrolünün Yeterliliğ̈ini Ölçmedeki Etkinliği İle İlgili "İç Denetim Mevzuatı" Sorularına Verilen Cevapların Ortalaması

\begin{tabular}{|c|c|c|c|c|c|}
\hline & $\mathbf{N}$ & Ort. & S.s & Min. & Max. \\
\hline $\begin{array}{l}\text { Mevcut olan tüm iç denetim mev zuatı etkin bir denetim } \\
\text { için yeterlidir. }\end{array}$ & 110 & 2,891 & 1,008 & 1,000 & 5,000 \\
\hline $\begin{array}{l}5018 \text { sayli kanunun iç denetimle ilgili kısmları } \\
\text { yeterlidir. }\end{array}$ & 110 & 2,427 & 0,953 & 1,000 & 5,000 \\
\hline $\begin{array}{l}\text { Tekrar eski sisteme dönülmesi etkin bir denetim için } \\
\text { gereklidir. }\end{array}$ & 110 & 1,827 & 0,800 & 1,000 & 4,000 \\
\hline $\begin{array}{l}\text { Iç denetim mevzuath, çalı̧anlarm iş yapma usullerimi } \\
\text { standartlaşturmaktadır. }\end{array}$ & 110 & 3,764 & 0,777 & 1,000 & 5,000 \\
\hline $\begin{array}{l}\text { Iç denetim, kamu iç kontrol ve iç denetim standartlarma } \\
\text { uygun olarak yaplmaktadır. }\end{array}$ & 110 & 3,673 & 0,836 & 1,000 & 5,000 \\
\hline $\begin{array}{l}\text { Kamu iç kontrol ve iç denetim standartları, iç den etimin } \\
\text { etkinliğmini ve başarııım artırmaktadır. }\end{array}$ & 110 & 3,836 & 0,807 & 1,000 & 5,000 \\
\hline $\begin{array}{l}\text { Kamu iç kontrol ve iç denetim standartları, Avrupa ve } \\
\text { Dünya'daki ömekl eriyle uyumludur. }\end{array}$ & 110 & 3,618 & 0,824 & 1,000 & 5,000 \\
\hline $\begin{array}{l}\text { Kamu iç kontrol ve iç denetim standartları eksiksiz ol arak } \\
\text { uygulanırsa iç denetim daha etkin ve başarll olur. }\end{array}$ & 110 & 4,164 & 0,698 & 2,000 & 5,000 \\
\hline $\begin{array}{l}\text { Kamu iç kontrol ve iç denetim standartları bu haliyle } \\
\text { eksikler içermektedir. }\end{array}$ & 110 & 3,391 & 1,032 & 1,000 & 5,000 \\
\hline $\begin{array}{l}\text { Kamu iç kontrol ve iç denetim standartlar bu haliyle } \\
\text { uygulanabilir değildir. }\end{array}$ & 110 & 2,518 & 0,946 & 1,000 & 5,000 \\
\hline
\end{tabular}


Tablo 11: Kurumun İç Kontrolünün Yeterliliğini Ölçmedeki Etkinliği İle İlgili "İç Denetim Sonrası Kurum Faaliyet Sonuçları" Sorularına Verilen Cevapların Ortalaması

\begin{tabular}{|c|c|c|c|c|c|}
\hline & $\mathbf{N}$ & Ort. & S.s & Min. & Max. \\
\hline $\begin{array}{l}\text { Iç denetim uygulamasıyla, kurumun faaliyetlerinde } \\
\text { etkinliği artmıştur. }\end{array}$ & 110 & 3,582 & 0,882 & 1,000 & 5,000 \\
\hline $\begin{array}{l}\text { Iç denetim uygulamasimin, kurumun toplam gelirlerine } \\
\text { yansmması olumlu olmuştur. }\end{array}$ & 110 & 3, & 0,946 & 1,000 & 5,000 \\
\hline $\begin{array}{l}\text { Iç denetim uygulamasıyla, kurumun toplam giderlerinde } \\
\text { azalma kaydedilmiştir. }\end{array}$ & 110 & 3,1 & 0,920 & 1,000 & 5,000 \\
\hline $\begin{array}{l}\text { Iç denetim uygulamasıyla, kurumun gelir ve gider } \\
\text { dengesinde olumlu gelişmeler olmuştur. }\end{array}$ & 110 & 3,1 & 0,836 & 1,000 & 5,000 \\
\hline $\begin{array}{l}\text { Iç denetim uygulamasıyla, kurumun yatırmmlarma etkisi } \\
\text { olumlu olmuştur. }\end{array}$ & 110 & 3, & 0,807 & 1,000 & 5,000 \\
\hline $\begin{array}{l}\text { Kurumdaki iç denetçi sayısı etkin bir denetim için } \\
\text { yeterlidir. }\end{array}$ & 110 & 3,155 & 1,198 & 1,000 & 5,000 \\
\hline Iç denetçi sayısı ile iç denetim rapor sayısı uyumludur. & 110 & 9 & 1,061 & 1,000 & 5,000 \\
\hline $\begin{array}{l}\text { Iç denetim raporlan kurumun etkinliğinin artmasma } \\
\text { olumlu katkıda bulunmaktadır. }\end{array}$ & 110 & 3,773 & 0,809 & 1,000 & 5,000 \\
\hline $\begin{array}{l}\text { Iç denetime geçildikten sonra kurum faaliyetleri daha } \\
\text { hızla ilerlemektedir. }\end{array}$ & 110 & 3,164 & 0,807 & 1,000 & 5,000 \\
\hline $\begin{array}{l}\text { Kurumda, iç den etim ile eğer varsa teftiş kurulunun görev } \\
\text { alanı konusunda bir görev karmaşası yaşanmaktadur. }\end{array}$ & 110 & 3,127 & 1,118 & 1,000 & 5,000 \\
\hline
\end{tabular}

Tablo 12: Araştırmaya Katılan Kamu İç Denetçilerinin İç Denetim Etkinlik Düzeylerinin Eğitim Durumu Değişkenine Göre Farklılaşması

\begin{tabular}{|c|c|c|c|c|c|c|}
\hline & Grup & $\mathbf{N}$ & Ort & Ss & $\mathbf{t}$ & $\mathbf{p}$ \\
\hline \multirow{2}{*}{ İç denetimin organizasyonu } & Lisans & 85 & 3,120 & 0,468 & $-1,794$ & 0,07 \\
\hline & Yüksek Lisans & 25 & 3,304 & 0,386 & & \\
\hline \multirow[t]{2}{*}{ İç denetim mevzuatı } & Lisans & 85 & 3,193 & 0,308 & $-1,118$ & 0,2 \\
\hline & Yüksek Lisans & 25 & 3,272 & 0,320 & & \\
\hline \multirow{2}{*}{$\begin{array}{l}\text { İç denetim sonrası kurum } \\
\text { faaliyet sonuçları }\end{array}$} & Lisans & 85 & 3,267 & 0,538 & $-0,071$ & 0,92 \\
\hline & Yüksek Lisans & 25 & 3,276 & 0,614 & & \\
\hline
\end{tabular}




\section{S. AKÇAY $\mid 18$}

Tablo 13: Araştırmaya Katılan Kamu İç Denetçilerinin İç Denetim Etkinlik Düzeylerinin Yaş Değişkenine Göre Farklılaşması

\begin{tabular}{lllllll} 
& Grup & N & Ort & Ss & $\mathbf{F}$ & $\mathbf{p}$ \\
İç denetimin & $32-37$ yaş & 22 & 3,277 & 0,445 & 1,364 & 0,251 \\
organizasyonu & $38-43$ yaş & 23 & 3,217 & 0,471 & & \\
& $44-49$ yaş & 32 & 3,100 & 0,411 & & \\
& $50-55$ yaş & 22 & 3,195 & 0,521 & & \\
& 56 yaş ve üstü & 11 & 2,927 & 0,390 & & \\
İç denetim mevzuatı & $32-37$ yaş & 22 & 3,168 & 0,320 & 2,673 & 0,036 \\
& $38-43$ yaş & 23 & 3,096 & 0,255 & & \\
& $44-49$ yaş & 32 & 3,238 & 0,333 & & \\
& $50-55$ yaş & 22 & 3,218 & 0,308 & & \\
& 56 yaş ve üstü & 11 & 3,445 & 0,238 & & \\
\hline İç denetim sonrası & $32-37$ yaş & 22 & 3,314 & 0,555 & 0,407 & 0,803 \\
kurum faaliyet & $38-43$ yaş & 23 & 3,165 & 0,623 & & \\
sonuçları & $44-49$ yaş & 32 & 3,272 & 0,625 & & \\
& $50-55$ yaş & 22 & 3,259 & 0,472 & &
\end{tabular}

Tablo 14: Araştırmaya Katılan Kamu İç Denetçilerinin İç Denetim Etkinlik Düzeylerinin Cinsiyet Değişkenine Göre Farklılaşması

Grup $\quad N \quad$ Ort $\quad$ Ss $\quad t \quad p$

İç denetimin organizasyonu

$\begin{array}{llllll}\text { Erkek } & 100 & 3,177 & 0,455 & 1,107 & 0,271\end{array}$

Kadın $\quad 10 \quad 3,010 \quad 0,451$ 
Sosyal Bilimler Dergisi 19

İç denetim mevzuatı

$\begin{array}{llllll}\text { Erkek } & 100 & 3,198 & 0,317 & - & 0,170 \\ \text { Kadın } & 10 & 3,340 & 0,207 & 1,382 & \\ \text { Erkek } & 100 & 3,269 & 0,569 & - & 0,996 \\ \text { Kadın } & 10 & 3,270 & 0,383 & & \end{array}$

Tablo 15: Araştırmaya Katılan Kamu İç Denetçilerinin İç Denetim Etkinlik Düzeylerinin Mesleki Kıdem Değişkenine Göre Farklılaşması

\begin{tabular}{|c|c|c|c|c|c|c|}
\hline & Grup & $\mathbf{N}$ & Ort & Ss & F & $\mathbf{p}$ \\
\hline \multirow{6}{*}{$\begin{array}{l}\text { İç denetimin } \\
\text { organizasyonu }\end{array}$} & \multirow[t]{2}{*}{10 y1l ve altı } & 7 & 3,13 & 0,46 & 3,00 & 0,05 \\
\hline & & 0 & 0 & 4 & 2 & 4 \\
\hline & \multirow[t]{2}{*}{$11-20$ yil } & 1 & 3,38 & 0,31 & & \\
\hline & & 9 & 4 & 0 & & \\
\hline & \multirow[t]{2}{*}{21 yıl ve üstü } & 2 & 3,06 & 0,49 & & \\
\hline & & 1 & 7 & 0 & & \\
\hline \multirow[t]{6}{*}{ İç denetim mevzuatı } & \multirow[t]{2}{*}{10 y1l ve altı } & 7 & 3,20 & 0,32 & 0,99 & 0,37 \\
\hline & & 0 & 9 & 5 & 9 & 2 \\
\hline & \multirow[t]{2}{*}{$11-20$ y1l } & 1 & 3,14 & 0,31 & & \\
\hline & & 9 & 2 & 7 & & \\
\hline & \multirow[t]{2}{*}{21 yıl ve üstü } & 2 & 3,28 & 0,25 & & \\
\hline & & 1 & 1 & 0 & & \\
\hline \multirow{6}{*}{$\begin{array}{l}\text { İç denetim sonrası kurum } \\
\text { faaliyet sonuçları }\end{array}$} & \multirow[t]{2}{*}{10 yıl ve altı } & 7 & 3,24 & 0,60 & 0,21 & 0,81 \\
\hline & & 0 & 9 & 5 & 1 & 0 \\
\hline & \multirow[t]{2}{*}{$11-20$ yil } & 1 & 3,34 & 0,33 & & \\
\hline & & 9 & 2 & 7 & & \\
\hline & \multirow[t]{2}{*}{21 yıl ve üstü } & 2 & 3,27 & 0,54 & & \\
\hline & & 1 & 1 & 6 & & \\
\hline
\end{tabular}

Anketin 1. Bölümündeki “İç Denetimin Organizasyonu” ile ilgili sorulara verilen cevaplara göre; 
İç denetimin yapısının, bazı eksiklikler giderildiği takdirde etkin ve başarılı sonuçlar almaya uygun bir yapıya sahip olduğu,

$>\quad$ İç denetimin yolsuzlukları başlamadan önleyecek bir yapıya sahip olduğu,

> İç denetçilerin kadro olarak Sayıştay, İç Denetim Koordinasyon Kurulu vb. bir başka kuruma bağlanmasının denetimin etkinliği açısından olumlu sonuçlar doğuracağı,

$>\quad$ İç Denetim Koordinasyon Kurulunun iç denetimin yapısındaki yeri ve rolü etkin bir iç denetim için yetersiz olduğu, sonuçlarına ulaşılmıştır.

Anketin 2. Bölümündeki "İç Denetim Mevzuatı" ile ilgili sorulara verilen cevaplara göre;

> 5018 Sayılı Kanun'un iç denetimle ilgili kısımlarının yetersiz olduğu,

$>\quad$ İç denetim sisteminin geleneksel denetimden daha etkin olduğu ve tekrar eski sisteme dönülmesinin gereksiz olduğu,

$>$ İç denetim mevzuatının çalışanların iş yapma usullerini standartlaştırdığı,

$>\quad$ İç denetimin kamu iç denetim ve kontrol standartlarına uygun olarak yapıldı̆̆ı,

$>\quad$ İç denetim ve iç kontrol standartlarının iç denetimin etkinliğini ve başarısını artırdığı,

> $\quad$ Iç̧ denetim ve iç kontrol standartlarının Dünya ve Avrupa ile uyumlu olduğu,

> İç denetim ve iç kontrol standartlarının eksiksiz olarak uygulanması durumunda iç denetimin daha etkin ve başarılı olacağı,

> İç denetim ve iç kontrol standartlarının uygulanabilir olduğu, bulgularına ulaşılmıştır.

Anketin 3. ve son bölümündeki "İç Denetim Sonrası Faaliyet Sonuçları" ile ilgili sorulara verilen cevaplara göre;

> İç denetim sonucunda kurumun faaliyetlerinde etkinliğinin arttığı,

$>\quad$ İç denetimin kurumun gelirlerine yansımasının olumlu olduğu,

$>\quad$ İç denetimin kurumun giderlerine yansımasının olumlu olduğu,

$>\quad$ İç denetimin kurumun gelir-gider dengesine yansımasının olumlu olduğu,

$>\quad$ İç denetim raporlarının kurumun etkinliğinin artmasına olumlu katkıda bulunduğu,

> İç denetim ile teftiş kurulu arasında bir görev karmaşası olduğu,

$>\quad$ İç denetim ile yatırımların artması ve azalması arasında ilişki olduğu, 
İç denetçi sayısı ile rapor sayısının uyumlu olduğu, bulgularına ulaşılmıştır.

\section{Sonuç ve Öneriler}

Araştırmada genel olarak elde edilen sonuçlar şunlardır:

* İç denetimin yapısının bazı eksiklikler giderildiği takdirde, daha etkin ve başarılı sonuçlar almaya elverişli olduğu,

* İç denetçilerin kadro olarak bulundukları kurumun dışında bağımsız bir kuruma bağlanmasının, iç denetimin bağımsızlığı anlamında önemli olduğuna ve iç denetimin etkinliğini artırabileceğine,

* İç Denetim Koordinasyon Kurulu'nun organizasyondaki konumu itibarıyla şu anda pasif bir konumda kaldığına dair bir algı olduğuna ve bu durumun da iç denetimin etkinliğini düşürmekte olduğuna,

* İç denetime kurumlarca gereken önem verilirse, kurumlardaki yolsuzluk ve suistimalleri başlamadan önleyebileceğine,

* İç denetim mevzuatında eksiklikler bulunduğuna, mevzuatın geç tamamlandığına, bu durumun da iç denetimin etkinliğini düşürdüğüne,

* İç denetimin etik kurallara ve mevzuata uygun olarak yapıldığında kuruma katma değer ekleme işlevini başarıyla yerine getireceğine,

* İç denetim standartlarının Avrupa ve Dünya'daki örnekleri ile uyumlu olduğuna ve standartların eksiksiz olarak uygulanması durumunda iç denetimin etkinliğinin artırabileceğine,

* İç denetim mevzuatının ve organizasyonunun tamamlandığında, faaliyet sonuçları üzerinde olumlu etkisi olabileceğine ve iç denetimin kurum gelirleri ile yatırımları artırabileceğine, giderleri minimize edebileceğine ve faaliyet sonuçlarına olumlu etki yapabileceğine dair tespitlerde bulunulmuştur.

\section{Araştırma sonuçlarına göre öneriler:}

İç Denetim Koordinasyon Kurulunun iç denetimin organizasyonunda daha aktif görev alarak iç denetimin etkinliğini artırabileceği önemli bir husus olarak görülmektedir.

$\checkmark \quad$ İç denetimin etkinliğinin artırılabilmesi için, yapısal birkaç değişikliğe gidilmesi gerekliliği önemli bir husus olarak ortaya çıkmaktadır. İç 
denetçilerin bağımsızlığı bağlamında, İ.D.K.K.'nın yeniden yapılandırılmasının ve daha etkin bir konuma getirilmesinin etkinlik anlamında önemli olacağı düşünülmektedir. Örneğin, İ.D.K.K., Hakimler ve Savcılar Yüksek Kurulu modeline benzer bir biçimde iç denetçilerin özlük ve sicil işlerinin takibini yapabilir. İç denetçiler ise kadro olarak yine bulundukları kurumda faaliyet gösterebilirler. Böylece, iç denetçilerin daha bağımsız denetim yapması ve denetimden daha etkin sonuç almaları sağlanabilir.

$\checkmark \quad$ İç denetimin daha etkin duruma getirilebilmesi için, mevzuattaki eksiklikler hızlı bir şekilde tamamlanmalıdır.

$\checkmark \quad$ Ayrıca, kurumlarda birçok münhal iç denetçi kadrosu bulunmakta, bazı kurumlarda ise iç denetim faaliyeti teftiş kurulları aracılığıyla yürütülmektedir. İç denetim birimleri oluşturulmamış olan kurumlarda, iç denetim birimleri acilen kurulmalı ve iç denetçi kadroları eksik olan tüm kurumlarda ise iç denetçi atamaları hızlı bir şekilde tamamlanmalıdır. Bu husus, iç denetimin kamuda etkinliğinin ve başarısının artırılabilmesi için çok önemli bir konu olarak görülmektedir.

Günümüzde, kurum faaliyetlerini sürekli iyileştirebilme açısından, iç denetim önemli bir unsur olarak görülmekte ve iç denetim konusunda yapılacak iyileştirmelerin kurumların geleceğine yapılan bir yatırım olacağı da unutulmamalıdır.

\section{Kaynakça}

Aksoy, T. (2008). Kamuda İç Kontrol ve İç Denetim. Ankara: Muhasebat Kontrolörleri Derneği Yayını.

Alptürk, E. (2008). İç Denetim Rehberi. Ankara: Maliye ve Hukuk Yayınları.

Arcagök, M.S., Erüz, E. (2006). Kamu Mali Yönetimi ve Kontrol Sistemi. İstanbul: Maliye Hesap Uzmanları Derneği Yayını.

Arslan, A. (2004). 5018 Sayılı Kamu Mali Yönetimi ve Kontrol Kanunu ile Kamu Harcama Sisteminde Yapılan Düzenlemeler. Mali Kılavuz Dergisi, 25.

Başpınar, A. (2009). Kamuda İç Denetim, İç Denetim Merkezi http://www.bumko.gov.tr/.../dg.ashx?...AhmetBaspinarKamudaic Denetim..PPT. (Erişim Tarihi: 19/05/2013).

Chapman, C. ve Anderson, U. (2003). Implementing The Professional Practices Framework. The Institute of Internal Aditors, 3. 
Dabbağoğlu, K. (2007). İç Kontrol Sistemi. Mali Çözüm Dergisi, 82, 164.

Ergin, H. (2007). Denetim. Kütahya: Dumlupınar Üniversitesi Yayınları.

Güçlü, F. (2008). Muhasebe Denetimi. Ankara: Detay Yayıncılık.

Haftacı, V. (2011). Muhasebe Denetimi. İstanbul: Avcı Ofset.

Hermanson, Dana R. (1994). The Internal Control Paradox: What Every Manager Should Know. Review of Business, 16, 29.

Jack, K. Scheiner, E. James, H. (1994). Auditing. Houghton Mifflin Company.

Kalaycı, Ş. (2006). SPSS Uygulamalı Çok Değişkenli İstatistik Teknikleri. Ankara: Asil Yayın Dağıtım Ltd. Şti.

Karaaslan, E. (2006). Kamu Harcamalarında Denetim. Ankara: Muhasebat Kontrolörleri Derneği Yayını.

Karasar, N. (2009). Araştırmalarda Rapor Hazırlama. Ankara: Nobel Yayınevi.

Kenger, E. (2001). Denetçi Yardımcıları Eğitim Notu. http://www.ydk.gov.tr/egitim notlari/denetim.htm. (Erişim Tarihi: 18/06/2013).

Özdamar, K. (2004). Paket Programlar ile İstatistiksel Veri Analizi 2: Çok Değişkenli Analizler. Eskişehir: Kaan Kitabevi.

Saraç, O. (2005). Kamu Yönetimi ve Kontrol Kanunu ile Yapılan Düzenlemelerin Değerlendirilmesi. Maliye Dergisi, 148, 27.

Sayıştay (2002). Performans Denetimi Kavramlar, İlkeler Metodoloji ve

Uygulamalar Kitapçı̆̆ı. Ankara. http://www.sayistay.gov.tr/tc/ perdenmetodoli.pdf (Erişim Tarihi: 17/06/2013).

5018 Sayılı Kamu Mali Yönetimi ve Kontrol Kanunu. Resmi Gazete, Sayı: 25326, Tarih: 24.12.2003. 